\title{
KEURING VAN KWALITEITSTUDENTE VIR 'N UNIVERSITEIT
}

\section{S.J.P. du Plessis}

Buro vir Universiteitsonderwys, Potchefstroomse Universiteit vir Christelike Hoër Onderwys

\section{ABSTRACT}

\section{THE SELECTION OF QUALITY STUDENTS FOR A UNIVERSITY}

During the period 1965-1985, there was a sharp increase in student numbers at universities in the RSA. The increase in student numbers was much higher than the economic or population increases. More and more matriculants apply for admission to university, despite the fact that university education has become very expensive. Nowadays the selection of students is more important than it has been in the past.

Selection is a very complicated process because people with different backgrounds, ideals and expectations are involved. There is also no test or examination that can accurately predict how a student is going to progress in a specific field of study at a certain university. Examinations of various examination bodies aren't equally effective predictors of academic achievement at university. There is also a difference in the standards of universities. In the same university different departments will demand more from a student than others. The mission and nature of a university can also determine whether a student is going to adapt to circumstances or not. World-wide, university admission requirements differ - there is a difference in this regard between universities in various countries as well as between universities in the same country.

In this article it is concluded that high-grade students ask for quality education in their homes, primary schools and secondary schools. However, under-privileged people with the potential to do well must be identified and admitted to the university.

There is a need for greater diversity in the tertiary education structure in South Africa. Community colleges can contribute in solving the Koers 54(2) 1989 
manpower problems and will help to reduce the number of university students. Accreditation of departments at universities together with proper selection of students can contribute to the maintenance of high standards at the university.

\section{INLEIDING}

Die opskrif van hierdie artikel dui aan dat universiteite diskrimineer sommige mense mag aan die universiteit studeer en ander mag nie.

As besluit moet word oor wie aan die universiteit mag studeer kom die vraag na die wese, plek en rol van die universiteit na vore. Die ondersoekspan van die Komitee vir Universiteitshoofde na makro-aspekte van die universiteitswese in die RSA het heel gou besef dat die universiteit deel is van $n$ groter maatskaplike orde en in wisselwerking is met ander instellings en sisteme. Vanweë die diverse aard van die SuidAfrikaanse samelewing is daar groot verskille in behoeftes, aansprake en waarde-oriëntasies en moet daar ruimte gelaat word vir verskillende beklemtonings by die vasstelling van die plek en rol van die individuele universiteit.

In die KUH-ondersoek is aangetoon dat daar polère spanningsverhoudings is wat elkeen ' $n$ kontinuum vorm waarbinne verskillend genuanseerde antwoorde oor die plek en rol van die universiteit gevind kan word (KUH, 1987:2). Aan die een kant verteenwoordig die universiteit sekere wardes wat die grondslag van alle deelwetenskappe vorm en het 'n universaliserende effek op die gees van die mens. Die universiteit streef akademiese waardes soos objektiwiteit, vrye en kritiese dialoog, openheid vir alternatiewe standpunte en intersubjektiewe kontrole van bevindings na. Die kulturele horison van die student moet aan die universiteit verruim word (p. 6).

Teenoor die universaliteit van die universiteit is daar egter die pool van partikulariteit. Die universiteit is ' $n$ sosiale instelling wat in 'n spesifieke kulturele en maatskaplike omgewing funksioneer. Die ondersteunersgemeenskap het sy eie taal, tradisies, gebruike, geskiedenis, strewes en waarde-oriëntasie. Die universiteit as onderwysinrigting is betrek by, en geïntegreerd binne, die formele kultuuroordrag wat vir die betrokke 
gemeenskap ontwikkel het (KUH, 1987:6). Hieruit blyk duidelik dat nie elke universiteit vir elke student geskik sal wees nie, al word akademiese meriete nie in ag geneem nie.

Die vraagstuk oor wie aan die universiteit mag studeer, het ook neerslag gevind in die elitisme - egalitarisme polère spanningsverhouding soos in die KUH-verslag verwoord (p.10). Die besprekings oor toelatingsvereistes in die vakliteratuur sowel as in die openbare pers kan veelal gereduseer word tot die vraagstuk of die universiteit moet strewe na akademiese uitmuntendheid (elitistiese uitgangspunt) en gevolglik strenge seleksiekriteria, gegrond op intellektuele vermoë en bewese prestasie, en of gelyke geleenthede vir alle mense gegee moet word om aan die universiteit te studeer (egalitaristiese benadering). In die uiterste toepassing van laasgenoemde benadering sal dus geen toelatingskriteria geld nie. ' $n$ Ander variasie is dat toelatingsvereistes vir minder bevoorregtes of hoe die groepe ook al genoem word, minder streng moet wees en dat hulle ook spesiale aandag tydens hulle studie moet ontvang.

Die bespreking verderaan oor keuring van universiteitstudente moet gesien word teen die agtergrond van die spanningsverhoudings hierbo genoem.

\section{IS KEURING VAN UNIVERSITEITSTUDENTE NODIG?}

Vanweë ' $n$ akademiese waardesisteem wat in die RSA heers is onderwys akademies gerig en word die universiteit deur baie as die finale plek van studie beskou. Baie mense wil graag aan die universiteit studeer omdat geglo word dat studie aan die universiteit ' $n$ versekering van 'n goeie betrekking en inkomste is. In die RSA, waar nagenoeg 508 van nuwe toetredes tot die arbeidsmark in die informele sektor werk sal moet vind en baie hulle eie werkgeleentheid sal moet skep, is dit ' $n$ verdraaide persepsie. Indien die matrikulante soos in die verlede na die universiteite stroom, sal die universiteite in die RSA binne 20 jaar moet verdubbel. Alleen uit 'n oogpunt van mannekrag om die onderrig te gee, is dit nie moontlik nie (Smit, 1988a:3). Keuring en kanalisering na ander opleidingsinrigtings kan hier 'n positiewe bydrae lewer. 
'n Verdere rede vir keuring van universiteitstudente is dat tesame met 'n geweldige groei in studentegetalle, die koste van universiteitsonderwys geweldig toegeneem het. In die RSA het studentegetalle van 59000 in 1965 tot 215000 in 1985 toegeneem. Die gemiddelde jaarlikse groeikoers van studente uit alle bevolkingsgroepe was 6,78 teenoor 'n jaarlikse toename van 1,88 van die totale bevolking en 'n ekonomiese groeikoers van 3,48 per jaar (KUH, 1987:23). Die groei in koste van universiteitsonderwys is ' $n$ wêreldwye tendens en daar is min lande wat hul eie hoër onderwys kan bekostig. Selfs 'n land soos Groot Brittanje wat baie selektief in sy toelating tot universiteite is en waar relatief min persone per duisend van die bevolking universiteitstudente is in vergelyking met ander ontwikkelde lande, is daar die afgelope paar jaar groot besnoeiings in universiteitsonderwys. Williams (1988:1) meld dat daar ten spyte van hoër studentegetalle sedert 1980 'n 128 afname in onderrigpersoneel aan Britse universiteite was. Tot 1991 sal Britse universiteite volgens voorspelling nog 7000 personeellede moet verloor.

Die omvang van die styging in studentegetalle wêreldwyd blyk uit Tabel 1 .

TABEL 1

Groei in inskrywingstal aan tersière onderwysinrigtings 1960-1980

\begin{tabular}{|c|c|c|c|}
\hline Streek & | & $\%$-toename & $1960-1980$ \\
\hline Ontw1kkelde lande & 1 & 214 & \\
\hline Ontwikkelende lande & 1 & 523 & \\
\hline Afrika & I & 709 & \\
\hline Latyns-Amerika & I & 831 & \\
\hline Suid-Astë & | & 411 & \\
\hline
\end{tabular}

UNESCO, 1983 Trends and projections, 1960-2000. Parys. (soos aangehaal deur Watson, K. 1988:144). 
Watson (1988:144-145) meld dat universiteitsonderwys wèreldwyd tientalle kere duurder is as primère onderwys. In sommige Afrikalande kan 80 kinders 'n primére skoolopleiding voltooi teen dieselfde koste as wat een universiteitstudent sy opleiding aan 'n universiteit kan voltooi.

In die RSA word daar volgens internasionale standaarde reeds die maksimum van die volksinkomste aan onderwys bestee. Die vinnig groeiende getal jeugdiges, veral onder swart geledere in ons land, noodsaak dat weer na die verdeling van die beskikbare fondse vir die onderwys gekyk word. In die lig van beperkte ekonomiese groei en spesifieke mannekragbehoeftes is dit logies dat duur universiteitsopleiding net vir sekere mense beskore kan wees (Smit, 1988b:5; De Vries, 1988:4).

Die mannekragbehoeftes van ' $n$ land eis kanalisering en keuring van universiteitstudente. Die feit dat daar in Eerstewèreldlande 'n hoë korrelasie bestaan tussen formele onderwys en ekonomiese groei, het die gedagte laat ontstaan dat onderwys die probleme van onderontwikkelde en ontwikkelende lande sal oplos. Onderwys is gesien as 'n sosiale en ekonomiese voordeel wat na alle vlakke van die bevolking uitgebrei moet word en dit sou help om vaardighede tuis te bring en houdings te verander. Daarmee saam sou dit industrialisering versnel. Om die rede is groot bedrae van die volksinkomste aan onderwys bestee. Aan die verwagtings is egter nie voldoen nie. Onderwys kan 'n bydrae tot ontwikkeling lewer, mits onderwys deur 'n omvattende program van mannekragbeplanning gerugsteun word (Le Roux, 1982:190-191). Die fout wat in Afrika gemak is deur aan te neem dat die teenwoordigheid van universiteite groei en ontwikkeling tot gevolg sal hè, is gedeeltelik ook in Suid-Afrika gemaak. In die geheel gesien het Suid-Afrika te veel universiteite in verhouding tot ander hoër onderwysinrigtings. Die akademiese waardesisteem veroorsaak dat die tradisionele akademiese onderwys verkies word bo ambags-, tegniese en natuurwetenskaplike onderwys (Dreijmanis, 1985:84). Die kurrikula op skool en gewilde studierigtings op universiteit veroorsaak dat hoofsaaklik werksoekers, en nie werkgewers nie, opgelei word.

Op tersière onderwysvlak word die voorkeur van universiteitsonderwys bo opleiding in tegniese en in sommige beroepsonderwysrigtings, $-156-$ 


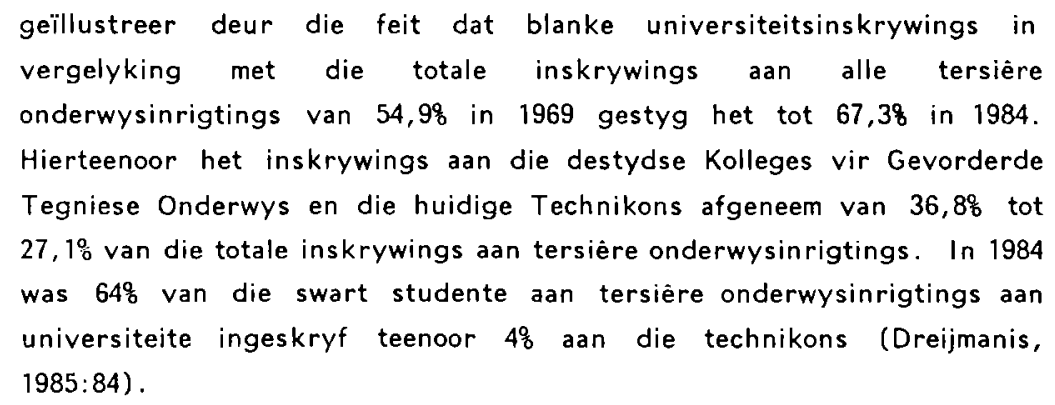

Weens die demokratisering van die onderwys is daar nou groot getalle studente met laer skolastiese prestasies as in die verlede wat na die universiteite kom. Navorsing het gewys dat studente met gemiddelde matrieksimbole van 'n C-simbool en hoër, die beste kans op universiteitsukses het. Studente met volle matrikulasievrystelling en gemiddelde A-, B-, C - en D-simbole het by 6 van die 17 universiteite in die RSA minder as die helfte van die 1985-studente-innames uitgemaak. Studente met gemiddelde $\mathrm{E}$-simbole (minder as $50 \%$ in matriek) maak by 'n hele aantal universiteite meer as een derde van hulle studentekorps uit (Smit, 1988:4). Daar is ' $n$ al groterwordende persentasie studente met 'n swak kans op uiteindelike sukses wat hulle by die universiteite aanmeld. Die sogenaamde simboolinflasie het meegebring dat skooleindresultate nie meer so ' $n$ betroubare aanduier van potensiële universiteitsukses is nie. Universiteitstoelatingsvereistes het die afgelope dekades eerder verslap as strenger geword te midde van 'n steeds groeiende getal matrikulante.

\section{WAAROM IS KEURING VIR TOELATING TOT DIE UNIVERSITEIT SO MOEILIK?}

Deur die jare is die invloed van 'n groot verskeidenheid faktore op akademiese prestasie op universiteit wêreldwyd ondersoek. Wat deurgaans gevind is, is dat vorige prestasie die enkele beste voorspeller van akademiese prestasie is (Monteith, 1988:1127). Dit is ook te verstane omdat ander faktore wat akademiese prestasie beïnvloed soos gemotiveerdheid, IK, studiehouding, studiemetodes, geslag, houding, sosioekonomiese status, seribrale hemisferiteit, leesbegrip, kreatiwiteit, akademiese selfbegrip en denkvlak, reeds ' $n$ rol by vorige prestasie gespeel het. Omdat vorige prestasie van voornemende studente geredelik 
beskikbaar is, is dit baie handig om as toelatingskriterium te gebruik. Alhoewel die beste voorspeller, is daar tog net 'n matige korrelasie tussen matriekprestasie en akademiese prestasie op universiteit. Vorige prestasie as kriterium sal dus nooit vir elke individu bevredig nie. Fourie (1986) het nagegaan wat die invloed van die inwerkingstelling van verhoogde universiteitstoelatingsvereistes in die vorm van hersiene vakgroepe, nuwe slaagvereistes in die vakgroepe en minimum groottotaal van 1050 in die matrikulasie-eksamen op die 1984-eerstejaarstudente aan die Rande Afrikaanse Universiteit wat in die Transvaal gematrikuleer het, sou wees. Hierdie toelatingsvereistes is gestel volgens die aanbevelings van 'n werkskomitee van die Gemeenskaplike Matrikulasieraad na navorsing oor die onderwerp deur die Raad vir Geesteswetenskaplike Navorsing (p.46-48). Van die groep van 1184 studente sou, met die toepassing van die nuwe vereistes, $25,7 \%$ nie toegelaat gewees het nie. Van die groep wat met die toepassing van die strenger toelatingsvereistes nie sou kwalifiseer nie, het $50 \%$ egter geslaag. Van die res wat wel toelating volgens die nuwe vereistes sou kry, het $64,4 \%$ geslaag (p. 51-52).

'n Verdere faktor wat die gebruik van matriekprestasie as toelatingsvereiste bemoeilik, is dat verskillende eksamineringsinstansies se uitslae nie dieselfde voorspellingsgeldigheid het nie. Mitchell en Fridjohn (1987) het aangetoon dat sommige van die blanke provinsiale onderwysdepartemente se eksamens vergelykbaar is, maar dat die eksamens van ander departemente van onderwys nie bruikbaar is as toelatingskriterium nie. Sodra studente van 'n wye verskeidenheid onderwysdepartemente dus by 'n universiteit aansoek doen om verdere studie, duik die probleem van die vergelykbaarheid van matrieksimbole op.

Ondersoeke wat handel oor die voorspelling van akademiese prestasie maak veral vergelykings tussen skoolprestasie en die eerstejaarprestasie (Van Wyk, 1988:4). Dit is vir die persoon wat moet besluit oor toelating egter belangrik om te weet of die student die studies kan voltooi. Die simpleks verskynsel, naamlik die afname in die verwantskap tussen skoolprestasie en die akademiese prestasie hoe verder die student vorder, bemoeilik voorspelling. 
Die verskillende studierigtings aan universiteite stel eiesoortige vereistes en uitdagings aan die student. Om dus 'n algemene kriterium soos groottotaal van matriekpunte aan te lé, is verdag. Selfs 'n spesifieke universiteitstoelatingseksamen soos die "Graduate Record Examinations" in die VSA (GRE) voorspel met wisselende sukses akademiese prestasies in die verskillende studierigtings (Thornell \& McCoy, 1985:415-419). Die ideaal sou dus wees dat daar vir elke moontlike studierigting eie toelatingseksamens ontwikkel moet word om sodoende die student se prestasie ten beste te kan voorspel. In die praktyk is dit egter moeilik omdat groot groepe studente aan die begin van die jaar by die universiteit opdaag en om 'n toetsprogram van so 'n groot omvang waarin elke individuele student vir sy besondere studierigting getoets kan word te loods, is feitlik onmoontlik. Ervaring leer ook dat baie studente met 'n sterk vooropgestelde voorkeur by die universiteit opdaag en selfs advies om ' $n$ ander studierigting te volg, nie in ag neem nie.

Die feit dat die gemiddelde ouderdom van die universiteitsbevolking besig is om te styg, maak voorspelling ook moeilik. In baie gevalle, veral van na-uurse studente, is die matriekeksamen reeds etlike jare gelede afgelè en is die punte nie meer betroubaar nie. Ouer studente het ook intussen ryper geword en die motiewe het ook verander. Hulle vorm dus eintlik 'n afsonderlike kategorie met die oog op toelatingsvereistes en prestasievoorspelling.

Standaarde aan universiteite verskit. In die VSA waar daar so 'n wye verskeidenheid van tersiēre onderwysinstellings is, word hierdie feit ruiterlik erken. In die KUH-verslag oor makro-aspekte van die universiteitswese (1987:92) word gemeld dat ondersoeke aangetoon het dat standaarde aan die onderskeie universiteite in die RSA grootliks varieer. Hierdie feit maak algemene voorspelling van universiteitsprestasie deur voornemende studente moeilik. Die student sou dus verskiltend presteer by verskillende universiteite.

Wat algemene keuring van studente bemoeilik, is dat elke universiteit sy eie missie en spesifieke karakter het. Universiteite is universeel in die sin dat daar op hoë vlak onderrig word, navorsing gedoen word en gemeenskapsdiens verrig word. Universiteite varieer egter grootliks wat akademiese standaarde en die aard van hulle aspirasies betref. Daar is -159 - 
nie 'n enkele, internasionaal aanvaarbare en praktiese model van presies hoe 'n universiteit daar uitsien nie. Daar is net spesifieke universiteite wat in spesifieke sosio-ekonomiese, politiese en historiese raamwerke bestaan en waaruit hulle ontwikkel het (Dreyer, 1982:47, 52). Elke universiteit sal van die volgende een verskil. Kulturele pluralisme is 'n proses wat steeds voortgaan en nie einde sal kry nie. Etnisiteit sal nie geleidelik van die toneel verdwyn nie, maar sal altyd voorkom. Taal en geloof was en sal altyd nog 'n belangrike verdeler ten opsigte van universiteitsonderwys wees. Al sou alle universiteite in Suid-Afrika ten volle oop wees, sal daar steeds universiteite wees wat hoofsaaklik Afrikaans-blank, Engels-blank en etnies-swart georiënteerd sal wees. So byvoorbeeld sal dit vir in swart student wat argumentsonthalwe Tswana as moedertaal het en die latere deel van sy skoolopleiding deur medium van Engels geniet het, moeilik wees om by in Afrikaanstalige universiteit in te pas. Die taalprobleem word geillustreer in navorsing wat aan 'n Afrikaanstalige universiteit gedoen is. Engelse handboeke word in die meeste fakulteite naas die hoeveelheid werk en die moeilikheidsgraad van die werk as die grootste enkele probleem in die onderrigleersituasie beskou. Die studente het baie meer probleme met Engelse handboeke as wat byvoorbeeld met die gehalte van onderrig ondervind word (Du Plessis, 1986:97). Weitzman (1982:191) stel dat ten spyte van die prestige van ' $n$ kollege daar nie een kollege is wat die beste vir almal is nie, en nie alle kolleges is net bedoel vir die bestes nie. Dit is nie net studente wat deur universiteite gekeur moet word nie; dit is ook studente wat universiteite moet keur om by hulle te pas.

'n Verskynsel in die RSA, maar ook in ander dele van die wèreld, is dat verskillende groepe nie proporsioneel op die universiteit verteenwoordig is nie en dat die prestasies van groepe ook verskil. Om oor toelating en veral regverdigheid in toelating te besluit, moet daar besluit word of regverdigheid beteken dat dieselfde toelatingsvereistes vir almal moet geld en of regverdigheid in toelating beteken dat die universiteitspopulasie 'n proporsionele verteenwoordiging van verskillende bevolkingsgroepe moet wees.

Vanweë die voertaal aan 'n universiteit is dit moeilik vir 'n universiteit om hom op alle groepe mense te rig. In die VSA is baie van die universiteite se missies sodanig dat hulle voorstaanders van die sogenaamde $-160-$ 
"affirmative action" is. Daar word dan ook in baie gevalle gepoog dat die studentepopulasie ook ' $n$ weerspieëling van die bevolkingsamestelling van die hele land moet wees. Anrig (1985) meld dat die afname in inskrywingstal in die VSA van minderheidsgroepe en nuwe druk om toelatingsvereistes vir studie aan die universiteit te verhoog, spanning skep. Verskillende toelatingsmodelle vir verskillende groepe is dan ook ondersoek. Om gelyke geleenthede vir alle groepe te skep, moet daar tussen groepe onderskei word. 'n Voorstel om bepaalde akademiese standaarde van eerstejaarstudente wat vanweë atletiekprestasies gewerf is te verwag, het groot teenkanting uitgelok omdat baie atlete van die minderheidsgroepe moeilik aan die akademiese standaarde kon voldoen (p.3-7). Dit is opvallend dat in die literatuur oor hierdie onderwerp in die VSA van "swak verteenwoordigde minderheidsgroepe" gepraat word. Studente van Asiatiese afkoms presteer as groep baie goed en kan nie saam met ander minderheidsgroepe gereken word nie.

Om die universiteitsbevolking ' $n$ weergawe van die bevolkingsamestelling te mak, is moeilik omdat die matrikulante nie daardie verhouding weerspieël nie. In die VSA is die getal studente van swak presterende minderheidsgroepe wat matrikuleer te klein om kolleges en universiteite in staat te stel om hulle "affirmative action"-doelstellings te bereik. 'n Gevolg hiervan is dat tersière onderwysinrigtings hulle toelatingsvereistes buig om proporsionele verteenwoordiging te kry. Studente wat so toegelaat word, is hoë-risikostudente. Meer as twee derdes van die swart nuwelingeerstejaarstudente en die helfte van die Spaanssprekendes in die staatsuniversiteitstelsel van Kalifornië kry toelating op hierdie wyse. Van die wat so toelating verkry het, voltooi net $7^{\circ} \circ$ van die swart studente en slegs 48 van die Spaanssprekendes 'n graad binne 5 jaar. Dié syfer vir blanke studente wat met spesiale vergunning toegelaat is, is 16\%; heelwat hoër as vir die ander groepe, maar nog ver onder die gemiddeld van die studente wat aan die normale toelatingsvereistes voldoen het (Richardson, Simmons en De los Santos, 1987:21). Studente van minderheidsgroepe wat wel aan die toelatingsvereistes voldoen, is gesog. Die Universiteit van Kalifornië in Los Angeles is baie gesog en net die beste blanke en Asiatiese studente word toegelaat. Die res word na ander kampusse van die universiteit verwys. Daarteenoor word alle swak verteenwoordigde minderheidsgroepe se studente wat aan die eerste toelatingsvereistes voldoen, toegelaat (21-22). 
Die gedagte dat sommige groepe studente net met 'n agterstand by die universiteit opdaag en met die geleenthede wat op die universiteit gebied word die prestasiegaping sal vernou, hou blykbaar nie steek nie. Wilson (1980:43) vind in sy ondersoek dat die "late-bloomer" hipotese vir minderheidsgroepe (swart, Indiaans en Suid-Amerikaans) nie steek hou nie. Hierdie hipotese stel dat minderheidsgroepe-studente besondere aanpassingsprobleme ondervind wat hulle eerstejaar-, maar nie hulle langtermynprestasie nie, beïnvloed. Wilson vind dat die voorspellingswaarde van toelatingseksamens in latere studiejare vir die minderheidsgroepe-studente selfs groter is as vir die ander studente. In 'n volgende studie (Wilson, 1981) vind hy dat minderheidsgroepestudente en ander studente aan die einde van 4 jaar op universiteit nog net so gedifferensieerd is ten opsigte van akademiese prestasie as wat dit die geval aan die einde van die eerste studiejaar was. Hy stel dat hierdie gegewens belangrike implikasies vir die seleksie, werwing en opvoedkundige programme vir minderheidsgroepe-studente het (p.373). Wat plaaslike ondersoeke oor die verskil in groepe betref, vind Van Aardt en Du Plessis (1987) dat swart en kleurling tekstielkundestudente in teenstelling met ander tekstielkundestudente oor die algemeen nog nie op die abstrakte denkvlak is nie.

In die RSA is reeds gevorder om akademiese ondersteuningsprogramme aan te bied. Die verslae oor die sukses en populariteit van hierdie akademiese ondersteuningsprogramme is volgens Tema (1988:29) ontmoedigend. Die rede daarvoor is 'n kombinasie van baie faktore. Dit is in oorvereenvoudiging on soos Zietsman en Gering (1986:25) te wil beweer dat 'n toelatingsbeleid gerig op "the removal of past discrimination without reference to race, class or creed", moontlik is. Waarskynlik word die woord diskriminasie hier ook gebruik om agterstande, om watter rede ook al, aan te dui. Agterstande wat opgebou is vanaf geboorte tot en met aankoms by die universiteit word nie in ' $n$ kort tyd reggestel nie. Mense is met verskillende gawes en talente gebore en daar moet daarteen gewaak word om nie in alle gevalle die rede vir swak prestasie toe te skryf aan faktore buite die studente geleë nie. Die uitgangspunt is egter suiwer dat universiteite toelatingskriteria moet aanlè wat die student wat oor die vermoëns beskik, maar wat swak presteer as gevolg van swak skoolonderrig, in staat kan stel om by toelating te kan kompeteer met studente wat in 'n stimulerende ouerhuis groot geword het en wat ook 
goeie onderrig ontvang het. Daar is ook praktiese probleme daaraan verbonde om spesiale toelatingseksamens of psigometriese toetse met die oog op keuring af te lé. Sommige studente moet ver afstande reis om die toetse af te lè en dit sal 'n groot teleurstelling wees om dan nie toelating te kry nie.

\section{HOE WORD GEKEUR?}

Uit die voorgaande is dit al duidelik dat keuring van universiteitstudente nie ' $n$ eenvoudige saak is nie. Die omvang van die probleem word geillustreer deur die wye verskeidenheid praktyke in hierdie verband. 'n Wye verskeidenheid van minder kwantifiseerbare inligtingsbronne soos onderhoude en getuigskrifte word benewens gestandaardiseerde toetse en skooleindeksamenuitslae gebruik. Die vraag sal egter steeds ontstaan of die regte beslissing gemaak is (Auld, 1984:276).

Die gebruik van toelatingstoetse sal altyd omstrede wees. Dit moet diskrimineer en sal nie minder kontroversieel wees as dit die bedoelde taak goed uitvoer as wanneer dit nie doeltreffend is nie (Hargadon, 1981:1113). Wright (1978) stel dat toelatingseksamens nie aangebore vermoë, dryfkrag en volharding kan meet nie. Die foutgrens sal altyd hoog wees en dit kan nie voorspel of 'n persoon in 'n bepaalde professie sal slaag nie. Hy stel voor dat waar nie-diskriminasie nagestreef word, daar benewens algemene toelatingskriteria ook die etniese verwantskap, behoeftes, sosio-ekonomiese status en mate van bevoorregting en ander relevante faktore in ag geneem moet word. Dit is natuurlik makliker gesè as gedaan.

Indien van gestandaardiseerde psigometriese toetse gebruik gemaak word, word almal aan dieselfde meting onderwerp en 'n objektiewe beoordeling is moontlik. ' $n$ Beperking is egter dat aspekte van die kandidaat se vermoëns getoets word. Kulturele en/of rasbevoordeling en 'n moontlike gebrek aan vergelykbaarheid tussen die toetsinhoud en die skoolkurrikulum mak hierdie toetse minder bruikbaar.

Word na die keuringspraktyke in verskeie lande gekyk, blyk dit dat daar 'n verskeidenheid benaderings is; keuring vind egter wel plaas. 
In die VSA word baiekeer verwag om een of meer van die sogenaamde "Graduate Record Examinations" se uitslae voor te lé. Oltman en Hartnett (1985:524) vind dat in 'n wisselende mate van die uitslae van hierdie eksamens gebruik gemaak word by toelating tot universiteite.

Alhoewel daar elke jaar van groot getalle voornemende studente verwag word om die resultate van psigometriese toetse soos die SAT (Scholastic Aptitude Test), of die ACT (American College Testing program) voor te lê, is daar nie in die VSA 'n enkele nasionale eksamen wat naastenby die rol speel wat die Baccalauréat in Frankryk, die Abitur in Wes-Duitsland of die "A-vlak"-eksamens in Engeland speel nie (Hargadon, 1981:1112). In 'n ondersoek waarin antwoorde van 1463 tersiêre instellings in die VSA verkry is, is aangedui dat die gegewens wat die meeste van applikante vereis word, die hoërskoolpunte is $\left(74^{\circ}\right)$. Wat die tweede meeste vereis word, is getuienis dat die hoërskoolopleiding voltooi is (718). Verder word dan toelatingstoetstellings soos die SAT of ACT vereis $\left(48^{\circ}\right)$. As gekyk word na hoe hierdie gegewens gebruik word, het dit uit die antwoorde van die instellings geblyk dat die grootste gewig by toelating geheg word aan die applikant se skoolprestasie, naamlik gemiddelde persentasie of stand in die groep (Hargadon, 1981:1114-1115). Daar is egter ook die sogenaande "oop deur" kolleges waar van studente geen kwalifikasie verwag word nie. Hargadon kom tot die gevolgtrekking dat dit in die VSA nie baie moeilik vir ' $n$ voornemende student is om by een of ander tersière onderwysinrigting geholpe te raak nie. Daar is van die universiteite wat baie hoë toelatingsvereistes stel, maar oor die algemeen laat die meeste kolleges en universiteite die meeste van die aansoekers toe om te studeer (p.1116). Daar word gebruik gemaak van verskillende kriteria deur die verskillende hoër onderwysinstellings en daar is maar baie min van hulle wat dieselfde waarde aan die verskillende kriteria heg (p.1117).

Toelatingstoetse het beperkings. Intellektuele nuuskierigheid en karakter en beginselvastheid is sake wat kwalik deur sulke toetse vasgestel kan word. Universiteite se toelatingsbeleid word ook veelal bepaal deur die aantal plekke beskikbaar vir die eerstejaarstudente. Slegs een uit elke tien kolleges in die VSA aanvaar minder as die helfte van die studente wat aansoek doen, terwyl omtrent een uit drie meer as $90 \%$ van alle aansoekers aanvaar ( $\operatorname{Linn}, 1982: 279$ ). 
In Engeland en Wallis word veral van die sogenaamde "Advanced Level"eksaminering van vakke gebruik gemaak om te dien as sif vir toelating tot die universiteit. Toelating tot universiteite in Groot Brittanje geskied nie outomaties nie. In aptekerswese doen jaarliks ongeveer 14000 studente aansoek om die ongeveer 1000 plekke wat beskikbaar is (Foy $\varepsilon$ Waller, 1987:691).

In Japan word benewens 'n algemene gesamentlike prestasietoets wat deur die nasionale en plaaslike universiteite landswyd op dieselfde dag afgeneem word, ook ' $n$ toets deur elke universiteit afgeneem. Hierdie toets word plaaslik saamgestel in die lig van die toelatingsbeleid van elke individuele universiteit (Ikeda, 1982).

In die Republiek van China word ook van 'n gesamentlike toelatingseksamen van universiteite en kolleges gebruik gemaak. Die selektiewe proses vir kolleges en universiteite bestaan reeds baie lank en alle hoërskoolleerlinge wat verder wil studeer, moet die toelatingseksamen aflè. Die eksamen neem twee dae in beslag en dek ses vakke waarvan drie verpligtend is, waaronder Chinees en Engels (Kuo, 1983). Dit is maar ' $n$ klein persentasie van die studente wat die eksamen aflè, wat wel toelating verwerf. Butterfield, soos aangehaal deur Hargadon (p.1113), meld dat ongeveer $10 \%$ van die 3 miljoen studente wat die eksamen aflè, die eksamen slaag.

Hierdie enkele voorbeelde is genoeg om aan te toon dat in die buiteland nie naastenby eenstemmigheid oor die aard en omvang van keuring is nie.

In die Republiek van Suid-Afrika word in die eerste plek hoofsaaklik van matriekeksamenuitslae gebruik gemaak om 'n afsnypunt te bepaal. Voornemende studente wat matrikulasievrystelling verwerf, kan dan tot die universiteit toegelaat word. Daar is egter van die universiteite wat volstaan met universiteitstoelating soos nog altyd deur die Gemeenskaplike Matrikulasieraad vasgelè is.

Sommige universiteite laat ook studente toe wat met voorwaardelike vrystelling kom inskryf. 
'n Wye verskeidenheid van psigometriese toetse word by sommige universiteite gebruik om 'n beeld van die eerstejaarstudent te probeer vorm. By sommige universiteite word studente nie gekeur op grond van psigometriese toetse nie, maar word dit gebruik on hulle te adviseer. By die Potchefstroomse Universiteit vir Christelike Hoër Onderwys word alle nuweling-eerstejaars onderwerp aan massatoetsing en die volgende toetse word afgelè: die Senior Aanlegtoetse, die 19-Veld-Belangstellingsvraelys, Persoonlike, Huislike, Sosiale en Formele-Verhoudingsvraelys (PHSF-verhoudingsvraelys), Opname van Studiegewoontes en -Houdings (OSGH) en Jung se Persoonlikheidsvraelys. Ander moontlikhede is denkvlaktoetse, leerstylvraelyste en taalvaardigheidstoetse.

As gekyk word na die verskillende toelatingseksamens en psigometriese toetse wat studente wèreldwyd, maar ook in die Republiek van SuidAfrika moet aflè, en daar word gekyk na die verskillende praktyke en prosedures daaromtrent, blyk dit duidelik dat die laaste woord oor keuring nog lank nie gespreek is nie.

\section{DIE PAD VORENTOE}

Om kwaliteitstudente vir die universiteit te keur, beteken dat daar genoeg aansoeke van kwaliteit moet wees. Daarvoor is nodig dat die produk van die primère en sekondère skole van gehalte moet wees. Die ouerhuis speel 'n groot rol om werksetiek vas te lè, te motiveer en 'n stimulerende omgewing te skep sodat dit nie nodig sal wees om spesiale oorbrugging tussen die ouerhuis en die skool te skep nie. Al word oorbruggingsprogramme op universiteit met oorgawe aangebied, kan dit nie jare se agterstande uitwis nie. Dit is ook te duur as die universiteit die skool se werk moet oor doen.

As na die toename van veral die getalle swart skoolkinders gekyk word, die relatiewe swak gekwalifiseerdheid van baie van die onderwysers, die swak sosio-ekonomiese omstandighede waarin baie van die kinders opgroei, kinderverwarlosing op baie terreine van hulle ontwikkeling en die druk op beperkte finansiële bronne, blyk dit dat hoë kwaliteitstudente vir alle universiteite $n$ ideal is waarvoor nog lank en hard gewerk sal moet word. Die kwaliteit van die voornemende universiteitstudent hang -166 - 
van baie faktore af wat 'n universiteitsoorbruggingsprogram of spesiale kursusse nie eers naastenby kan hanteer nie.

Universiteite sal minder noodsaak hè om studente te keur indien daar groter diversiteit in die tersière onderwysstruktuur in die RSA is. Omdat die universiteit vir 'n lang tyd gesien is as feitlik die enigste plek waar 'n matrikulant kan gaan studeer, het tersiêre onderwys in die RSA eensydig ontwikkel. 'n Groter getal tersière onderwysinrigtings, anders as universiteite, kan die getalledruk op universiteite laat afneem en 'n meer markgerigte tersiêre opleiding tot gevolg hè. Die beeld van die technikons moet uitgebou word sodat meer studente na technikons gelok word. Technikons het tans minder as een derde van die universiteit se studentegetalle. Die totstandkoming van gemeenskapskolleges kan, moontlik soos in die VSA, verder sorg vir balans in die tersiêre onderwys en kan ook vir sommiges as deurgang na die universiteit dien. Op hierdie wyse word ook al gekeur. In die VSA is gevind dat heelwat studente na voltooiing van studies aan die gemeenskapskollege universiteitstoelating verkry, maar dit nie opvolg nie, ondat hulle alreeds grootliks vir 'n beroep voorberei is. Bernstein (1988:4) rapporteer dat hoër onderwys in die VSA 'n groot verandering ondergaan het as gevolg van die totstandkoming van gemeenskapskolleges. In die VSA was daar in 19552,5 miljoen studente. Vandag is daar 12 miljoen. Daar is bereken dat in die tienjaarperiode van 1960 tot 1970, 'n nuwe gemeenskapskollege elke 10 dae tot stand gebring is. In die twintigjaarperiode van 1960 tot 1980 het die gemeenskapskollege-inskrywings tienvoudig toegeneem tot oor die 4,5 miljoen. Teen 1980 het hierdie kolleges meer as die helfte van die studente in die VSA ingeskryf. Universiteite sou nie al hierdie studente kon akkommodeer nie. In die Verenigde Koninkryk help die Colleges of Higher Education om saam met die Universiteite en Polytechnics om gebalanseerde hoër onderwys te verskaf. Japan het naastenby net soveel Junior Kolleges as wat daar universiteite is. Tweeen driejarige kursusse word aangebied en krediete kan uitpresteer word wat erkenning vir graadstudie geniet. Nagenoeg 908 van hierdie kolleges is in privaatbesit. Alhoewel die oorgrote meerderheid van die studente dames is, help dit tog om die groot druk wat reeds op universiteite in Japan geplaas word, te versag (Anon., 1984:231). 
Universiteite moet hulle missies duidelik stel. Elke universiteit kan nie alles wil wees vir almal nie en duidelike missiestellings sal help dat studente aansoek vir toelating by universiteite en ander tersière onderwysinstellings doen war dit hulle die beste pas. Elke universiteit moet besluit waar hy, binne die definisie van ' $n$ universiteit, op die universaliteit-partikulariteit kontinuum wil lè. Dit sal sy keuring vanselfsprekend beïnvloed. Dieselfde geld vir die elitisme egalitarisme spanningsverhouding. Die universiteit kan nie akademies uitmuntend wees en terselfdertyd groot getalle studente inneem, wat slegs met langdurige, intensiewe aandag, enigsins ' $n$ kans staan om ' $n$ graad te verwerf nie. Herbert London stel dat in die VSA tans studente op kampusse is wat voor 1960 nie daar sou gewees het nie. 'n Begeerte om hoër onderwys te "demokratiseer" het veroorsaak dat baie minderheidsgroepe-studente op kampusse afgelaai is met die verwagting dat wonderwerke gaan gebeur. Die gevolg was verlaging van standaarde en die universiteitsgraad het baie van sy betekenis verloor (1988:58).

Elke universiteit moet binne sy eie missie sy toelatingsvereistes stel. Die toelatingsvereistes moet vir die toegelate student 'n mate van versekering gee dat, indien hy toegewyd werk, daar 'n redelike kans op sukses is. Dit is noodsaaklik dat navorsing oor keuring vir studie aan fakulteite en in spesifieke studierigtings voortdurend gedoen moet word, om in die lig van die omstandighede van die dag, studente te adviseer en te kanaliseer.

'n Groot vrees by die algemene publiek, maar ook onder akademici, is dat die standaarde wat deur die eeue 'n kenmerk van universiteite was, in die slag kan bly. Keuring van studente en akkreditering van akademiese departemente kan hier as waghorid optree. Akkreditering kan help dat hoë gehalte studente in sekere studierigtings ook nie te dun oor te veel departemente versprei word nie. Wie as akkrediteerder van akademiese departemente sal optree, is nie hier ter sake nie. Wat wel ter sake is, is dat net gehalte departemente met gehalte dosente en navorsers hoë gehalte studente kan eis. Navorsing oor akkreditering in die Suid-Afrikaanse konteks sal egter nog gedoen moet word omdat "akkreditasie, soos dit tans in die VSA voorkom, nie op natuurlike wyse in die huidige politieke en statutére konteks van ons universiteitstelsel sal inpas nie" (Departement van Nasionale Opvoeding, 1987:76). 
Dosente, studente, besluitnemers in die universiteitsonderwys en die algemene publiek sal graag 'n enkele keuringstoets wil sien wat objektief, geldig en regverdig is. As egter aan belanghebbendes gevra sal word om aan die woorde regverdigheid, geldigheid en objektiwiteit in universiteitskeuringsverband inhoud te gee, sal nie alleen tussen verskillende universiteite nie, maar ook tussen dosente van dieselfde universiteit, 'n wye spektrum van betekenisse gekry word. Die onmoontlikheid van so 'n enkele toets of eksamen sal duidelik blyk. Om egter status wat deur die eeue opgebou is te behou, in landsbelang, mar ook in die belang van applikante wat nie oor die nodige intellektuele vermoëns beskik nie, moet keuring plaasvind. Elke ware universiteit sal in die lig van sy missie, studente voortdurend op sy eie wyse moet keur.

\section{BIBLIOGRAFIE}

ANON. 1984. Japan. (In International handbook of education systems, $3: 209-250$.)

ANRIG,G.R. 1985. A challenge for the State: Protecting university access within systemwide admissions standards. AAHE Bulletin : 3-7, May

AULD, L. 1984. GRE analytical ability as an admissions factor. Library Quarterly, 54(3): 265-276.

BERNSTEIN, ALISON. 1988. Community colleges: coming of age. Change, Jan./Feb.

DEPARTEMENT VAN NASIONALE OPVOEDING. kyk SUID-AFRIKA (Republiek). Departement van Nasionale Opvoeding.

DE VRIES, M. 1988. Aar van opvoeding afgesny. Beeld: 4, Okt. 26.

DREYER, H.J. 1982. The university in a developing society. Koers, $47(1): 45-54$ 
DREIJMANIS, J. 1985. The role of government in tertiary education: The case of South Africa since 1945. Potchefstroom. 209p. (Proefskrif (D. Phil.) - PU vir CHO.)

DUMONT, R.G. \& TROELSTRUP, F.L. 1981. Measures and predictors of educational growth with four years of college. Research in Higher Education, 14(1):31-47.

DU PLESSIS, S.J.P. 1986. Verslag oor akademiese en verwante aangeleenthede van veral voorgraadse studente aan die $\mathrm{PU}$ vir CHO. Deel I. Potchefstroom : PU vir CHO, Buro vir Universiteitsonderwys. 70p.

DU PLESSIS, S.J.P. 1987a. Derde Wèrelduniversiteit vir 'n Derde Wèreldland. RAU Bulletin vir Dosente, 19(2):17-24, Augustus.

DU PLESSIS, S.J.P. 1987b. "Distance Education at a residential university". (Referaat gelewer tydens "Distance Education Conference", UNISA. 18-21 Mei 1987) Volume 2 - konferensiebundel.

FOURIE, C.M. Invloed van die voorgestelde matrikulasievrystellingsvereistes van die GMR op eerstejaarinname. RAU Bulletin vir Dosente, 18(2):45-54, Augustus.

FOY, J.M. E WALLER, D.J. 1987, Using British school examinations as a predictor of university performance in a pharmacy course: $A$ correlative study. Higher Education, 16:691-698.

HARGADON, F. 1981. Tests and college admissions. American Psychologist, 36(10):1112-1119, October.

HUTCHINGS, P. \& REUBEN, E. 1988. Faculty voices on assessment. Change: $48-55$, July/August.

IDEKA, H. 1982. A new development of university entrance examination in Japan. (Paper presented on 26 July 1982 at the Annual Meeting of the International Congress of Applied Psychology.) Edinburgh, Scotland. $24 p$. 
IDEKA, H. 1986. On the present status of the joint first-stage achievement Test (JFAT) of selecting university entrants in Japan. (Paper presented on 19 April 1986 at the National Council on Measurement in Education.) San Francisco. 28p.

KUH. KOMITEE VIR UNIVERSITEITSHOOFDE. 1987. Verslag van die hoofkomitee van die KUH-ondersoek na makro-aspekte van die universiteitswese binne tersière onderwysverband in die RSA. Pretoria. $135 p$.

KUO, W. 1983. Nation-wide College Entrance Examination - Current practice and critical issues. (Paper presented on 28-30 September 1983 at the International symposium commemorating the tenth anniversary of the University of Tsukuba.) Japan. 13p.

LE ROUX, LINDA, 1982. Onderwys in Afrika: Ontwikkeling of onderontwikkeling? Koers, 47(3): 189-198.

LINN, R.L. 1982. Admissions testing on trial. American Psychologist, $37(3): 279-291$, March.

LONDON, H. 1987. Why we face the death of the university, USA Today: 32-36, Sept.

MITCHELL, G. \& FRIDJOHN, P. 1987. Matriculation examinations and university performance. South African Journal of Science, 83(9):555-559.

MONTEITH, J.L. de K. 1988. Faktore wat die akademiese prestasie van eerstejaarstudente beïnvloed. (In Suid-Afrikaanse Vereniging vir Navorsing en Ontwikkeling in die Hoër Onderwys. Vernuwing in die hoër onderwys: referate gelewer by die vyfde kongres van SAVNOHO gehou op 12 en 13 Januarie 1988 te Potchefstroom. Potchefstroom. p. 106-115.)

OLTMAN, P.K. \& Hartnett, F.T. 1985. The role of the graduate record examinations in graduate admissions. Journal of Higher Education, 56(5): 623-537, Sept/Oct. 
RICHARDSON, R.C., SIMMONS, A. $\varepsilon$ De los SANTOS, A.G. 1987. Graduating minority students. Change: 20-35, May/June.

SCHAFFNER, P.E. 1985. Competitive admission practices - when the SAT is optional. Journal of Higher Education, 56(1):54-72, Jan, /Feb.

SMIT, P. 1988a. Die toekoms van die universiteitswese in Suid-Afrika. (Referaat gelewer op 12 Januarie 1988 tydens die kongres van die SuidAfrikaanse Vereniging vir Navorsing en Ontwikkeling vir die Hoër Onderwys te Potchefstroom.) Universiteit van Pretoria. 17p.

SMIT, P. 1988b. Universiteite se funksie bedreig. Beeld: 5, Nov. 11.

SUID-AFRIKA (Republiek). Departement van Nasionale Opvoeding, 1987. Akademiese standaarde by universiteite in die RSA. Pretoria. 90p. (NASOP 02-129(98/10.)

TEMA, B.O. 1988. Academic support: its assumptions and implications. South African Journal of Higher Education, 2(1):29-34.

THORNELL, J.G. \& MCCOY, A. 1985. The predictive validity of the graduate record examinations for subgroups of students in different academic disciplines. Educational and Psychological measurement, 45:415-419.

VAN AARDT, A.M. \& DU PLESSIS, S.J.P. 1988. Cognitive development among students of textile science at university. South African Journal of Science, 84(5):442-444, May.

VAN WYK, C.K. 1988. Die voorspelling van derdevlakwiskundeprestasie aan in universiteit. Potchefstroom. 241p. (Proefskrif (D.Ed.) - PU vir CHO.)

WATKINS, D. 1986. Learning processes and background characteristics as predictors of tertiary grades. Educational and Psychological Measurement, 46:199-203. 
WATSON, K. 1988. Forty years of education and development: from optimism to uncertainty. Educational Review, 40(2):137-174.

WEITZMAN, R.A. 1982. The prediction of college achievement by the scholastic aptitude test and the high school record. Journal of Educational Measurement, 19(3):179-191, Fall.

WILLIAMS, Elaine. 1988. Leadership risked as UGC predicts 5000 job losses. The Times Higher Education Supplement 797:4, 12 Feb.

WILSON, K.M. 1980. The performance of minority students beyond the freshman year: testing a "late-bloomer" hypothesis in one state university setting. Research in Higher Education, 13(1):23-47.

WILSON, K.M. 1981. Analyzing the long-term performance of minority and non-minority students: A tale of two studies. Research in Higher Education, 15(4):351-375.

WRIGHT, S.J. 1978. Testing / Admissions: what can and cannot be done. (Paper presented in October 1978 at a seminar for state leaders in postsecondary education.) Durban. $12 p$.

ZIETSMAN, A. E GERING, M. 1986. Admission to university in an academically non-homogeneous society. Higher Education, 15:25-35. 